\title{
Molecular cloning and sequence analysis of multiple cDNA variants for thyroid-stimulating hormone $\beta$ subunit (TSH $\beta)$ in the fathead minnow (Pimephales promelas)
}

\author{
Sean C. Lema Jon T. Dickey Penny Swanson
}

\begin{abstract}
We cloned and sequenced full-length cDNAs encoding the $\beta$ subunit of thyroid-stimulating hormone (TSH $\beta$ ) from the pituitary of fathead minnow (Pimephales promelas) using 5'- and 3'-rapid amplification of cDNA ends (RACE). Three cDNA variants for TSH $\beta$ with lengths of 1184-, 1093-, and 818-bp were identified. The cDNA variant of 1184-bp included 453-bp of open-reading frame and 610 -bp of $3^{\prime}$ UTR followed by a poly(A)site. This cDNA encodes 150 amino acids including a 19 residue signal peptide and a mature TSH $\beta$ protein of 131 residues with sequence identities of $97-53 \%$ to other fishes and $42-39 \%$ to mammals. The $1093-\mathrm{bp}$ cDNA variant was identical to the $1184-\mathrm{bp}$ variant in the open-reading frame, but contained a deletion of $40-\mathrm{bp}$ in the $3^{\prime \prime}$ UTR. The $818-\mathrm{bp}$ cDNA variant, however, contained 498-bp of open-reading frame followed by 227-bp of $3^{\prime \prime}$ UTR and a poly(A)site. The deduced amino acid sequence for this cDNA variant showed $99.2 \%$ homology with the 1184- and 1093-bp variants of TSH $\beta$, but a single deletion of 332bp nucleotides spanning the predicted stop codon and $3^{\prime \prime}$ UTR resulted in a deduced amino acid sequence with 15 additional residues on the $\mathrm{C}$ terminus. The presence of this $818 \mathrm{-bp}$ cDNA variant in the pituitary was further confirmed by PCR using primers developed to the $5^{\prime}$ and $3^{\prime}$ UTR. PCR and Southern blot analyses of genomic DNA suggested only one gene for TSH $\beta$. Sequencing of this gene revealed a hairpin loop structure of approximately 300-bp located in the $3^{\prime \prime} \mathrm{UTR}$ and corresponding to the region of the 332-bp deletion in the 818-bp transcript.
\end{abstract}

Keywords: Thyroid-stimulating hormone; Thyrotropin; TSH; Fathead minnow; cDNA variants; mRNA transcripts; Hairpin loop; Fish

\section{Introduction}

Thyroid-stimulating hormone (TSH, thyrotropin) is a glycoprotein released from the adenohypophysis to activate iodine uptake, thyroid hormone synthesis, and the release of thyroid hormone from the thyroid gland (Szkudlinski et al., 2002). Similar to other glycoprotein hormones, TSH is a heterodimeric hormone composed of two noncovalently bound protein subunits ( $\alpha$ and $\beta$ ) that are syn- thesized separately but combine to form the functional hormone. The $\alpha$ subunits of TSH, follicle-stimulating hormone (FSH), luteinizing hormone ( $\mathrm{LH})$, and human chorionic gonadotropin (hCG) are identical, and structural variation among the $\beta$ subunits mediates the receptor specificity and biological action of each glycoprotein hormone.

In fish, mRNA for the $\beta$ subunit of TSH (TSH $\beta$ ) has been isolated and the cDNA sequenced from select species of Salmonids (Ito et al., 1993; Martin et al., 1999), Anguillids (Han et al., 2004; Salmon et al., 1993), and Cyprinids (Chatterjee et al., 2001; Yoshiura et al., 1999). However, $\mathrm{TSH} \beta$ has not previously been cloned from the fathead minnow (Pimephales promelas), a widely utilized model species for toxicological research (Ankley and Villeneuve, 
2006). Small fishes including the fathead minnow are increasingly used to evaluate potential endocrine disrupting chemicals (EDCs) (USEPA, 2002; Ankley and Johnson, 2004), yet there is still a need in many of these species to develop molecular markers for the hypothalamic-pituitary-thyroid axis. A number of EDCs including polychlorinated biphenyls (PCBs) and brominated flame retardants (e.g., PBDEs) are known to alter plasma thyroid hormone levels, but little is known about the mechanisms by which these chemicals act (Brown et al., 2004). Sequencing the TSH $\beta$ transcript from fathead minnow will permit evaluation of how these and other EDCs influence the thyroid axis at the level of the pituitary gland. In the current study, we used 5'- and 3'-rapid amplification of cDNA ends (RACE) on RNA extracted from the pituitary gland to identify full-length cDNAs for TSH $\beta$ from fathead minnow.

\section{Materials and methods}

\subsection{Total RNA isolation}

Fathead minnow (Pimephales promelas) adults were obtained from Environmental Consulting \& Testing (Superior, WI). Minnows were euthanized in tricaine methanesulfonate (MS222; Argent Chemical, Redmond, WA), and pituitaries were dissected, pooled, and frozen immediately in liquid nitrogen. Female and male pituitaries were pooled separately. Brains were also dissected, frozen, and stored from each fish individually. All tissues were stored at $-80^{\circ} \mathrm{C}$.

Total RNA was extracted from the pooled pituitary tissues of adult female minnows ( $n=12$; mass, $0.97 \pm 0.6 \mathrm{~g}$; length, $43.8 \pm 1.2 \mathrm{~mm}$, mean $\pm \mathrm{SEM}$ ) since the amount of total RNA obtained from a single pituitary was insufficient for cloning. Total RNA was isolated in TriReagent (Molecular Research Center, Cincinnati, OH) and quantified by spectrophotometry (260:280 ratio of 2.01; NanoDrop Technologies, Wilmington, DE). RNA quality was confirmed by electrophoresis on a $1 \%$ agarose gel.

\section{2. $c D N A$ cloning of TSH $\beta$ from fathead minnow}

\subsubsection{Determination of a partial $c D N A$ sequence for $T S H \beta$}

To obtain a partial cDNA sequence, first-strand cDNA was synthesized in a $20 \mu \mathrm{l}$ reverse transcription reaction by incubating $2 \mu \mathrm{g}$ of total RNA template $(4.36 \mu \mathrm{l})$ with $1.0 \mu \mathrm{l}$ PCR nucleotide mix $(10 \mathrm{mM}$ of dCTP, dGTP, dTTP, and dATP, Promega, Madison, WI), $0.5 \mu \mathrm{l}$ of random primers (Promega), and $6.14 \mu \mathrm{l}$ of RNAase-free $\mathrm{H}_{2} \mathrm{O}$ (Sigma) at $65^{\circ} \mathrm{C}$ for 5 min. Subsequently, $4 \mu \mathrm{l}$ of $5 \times$ buffer, $2 \mu \mathrm{l}$ of 0.1 M DTT, $1 \mu$ of RNase inhibitor, and $1 \mu \mathrm{l}$ of Superscript II reverse transcriptase (Invitrogen, Carlsbad, CA) were added, and the mixture was incubated at room temperature for $10 \mathrm{~min}$ followed by $42^{\circ} \mathrm{C}$ for $50 \mathrm{~min}$ and $70^{\circ} \mathrm{C}$ for $15 \mathrm{~min}$.

PCR was performed using degenerate primers designed from consensus regions of cDNA sequences for TSH $\beta$ from other cyprinid fishes (zebrafish, Danio rerio, GenBank Accession No. AY135147, Herzog et al., 2003; goldfish, Carassius auratus, Accession No. AB003584, Yoshiura et al., 1999; common carp, Cyprinus carpio, Accession No. AB003585; and bighead carp, Aristichthys nobilis, Accession No. AF177471, Chatterjee et al., 2001). The primers used were (forward) $5^{\prime}-\mathrm{TGC}(\mathrm{A} / \mathrm{C}) \mathrm{CCAC}(\mathrm{C} /$ T) GA(G/C)TACAC(C/T)AT- $3^{\prime \leftarrow}$ and (reverse) 5'-CTCATACTG $(\mathrm{G} /$ T)TCCCAATA $(\mathrm{C} / \mathrm{T}) \mathrm{GC}(\mathrm{C} / \mathrm{T}) \mathrm{TGG}-3^{\prime}$. First-strand cDNA was amplified in a $50 \mu \mathrm{l}$ PCR containing $2 \mu \mathrm{g}$ of reverse-transcribed cDNA from the pooled female pituitaries (GeneAmp PCR System 2400; Perkin-Elmer, Wellesley, MA) using a thermal profile of $94{ }^{\circ} \mathrm{C}$ for 2 min followed by
30 cycles of $94{ }^{\circ} \mathrm{C}$ for $30 \mathrm{~s}, 50^{\circ} \mathrm{C}$ for $30 \mathrm{~s}$, and $72{ }^{\circ} \mathrm{C}$ for $1 \mathrm{~min}$, and ending with $72{ }^{\circ} \mathrm{C}$ for $10 \mathrm{~min}$. Each PCR was replicated three times, and the resulting cDNA was pooled. Electrophoresis on a $1.2 \%$ agarose gel revealed a band of predicted size, so the cDNA was purified (QIAquick PCR Purification Kit, Qiagen, Inc., Valencia, CA) and sequenced on an ABI PRISM 3100 Genetic Analyzer using a ABI Big Dye Terminator Cycle Sequencing Kit v3.1.

\subsubsection{Cloning and sequencing of full-length $c D N A$ s for TSH $\beta$}

Nested primers specific to fathead minnow TSH $\beta$ were designed from the partial cDNA sequence obtained above and used to acquire the fulllength sequence by $5^{\prime}$ - and $3^{\prime}$-rapid amplification of cDNA ends (BD SMART RACE cDNA Amplification Kit, Clontech Laboratories, Inc., Mountain View, CA). The outer-nested primers were (forward) $5^{\prime}$-GT GAAGGAGTTGGTGGGTCCTCGTTTCC- $3^{\prime \prime}$ and (reverse) $5{ }^{\prime}$-CTCCT CAGGGTCGGGGTACAGATGTCGG- $3^{\prime \prime}$. The inner-nested primers were (forward) $5^{\prime}$-CGGACGGCCATCTTGCCTGGCTGT- $3^{\prime \leftarrow}$ and (reverse) 5'-GGGCACATTCGTCACTGTGGGTGTTACA-3' ${ }^{\prime}$. Firststrand cDNA was amplified in a $50 \mu \mathrm{l}$ PCR containing $0.02 \mu \mathrm{g}$ of reverse-transcribed cDNA from the pooled pituitaries of female minnows under a thermal profile of 5 cycles of $94{ }^{\circ} \mathrm{C}$ for $30 \mathrm{~s}$ followed by $72{ }^{\circ} \mathrm{C}$ for $2 \mathrm{~min} ; 5$ cycles of $94^{\circ} \mathrm{C}$ for $30 \mathrm{~s}, 70^{\circ} \mathrm{C}$ for $30 \mathrm{~s}$, and $72{ }^{\circ} \mathrm{C}$ for $2 \mathrm{~min}$, and then 25 cycles of $94{ }^{\circ} \mathrm{C}$ for $30 \mathrm{~s}, 68^{\circ} \mathrm{C}$ for $30 \mathrm{~s}$, and $72{ }^{\circ} \mathrm{C}$ for $2 \mathrm{~min}$. Electrophoresis of the $5^{\prime} \mathrm{RACE}$ product on a $1.2 \%$ agarose gel revealed a single band, while the $3^{\prime} \mathrm{RACE}$ product produced multiple bands. The $3^{\prime \prime}$ RACE bands were excised from the gel and purified using a Qiaex II Gel Extraction Kit (Qiagen, Inc.). A second round of PCR was performed on each purified band using the inner-nested primers and thermal conditions of $95^{\circ} \mathrm{C}$ for $2 \mathrm{~min}$ followed by 30 cycles of $95^{\circ} \mathrm{C}$ for $30 \mathrm{~s}, 60^{\circ} \mathrm{C}$ for $30 \mathrm{~s}$, and $72{ }^{\circ} \mathrm{C}$ for $1 \mathrm{~min}$, and then $72{ }^{\circ} \mathrm{C}$ for $2 \mathrm{~min}$ to confirm that these PCR amplicons were TSH $\beta$.

The cDNA was ligated into plasmid (Novagen Perfectly Blunt ${ }^{\circledR}$ Cloning Kit, pSTBlue-1, EMD Biosciences, Inc.) and transformed into ampicillin resistant bacteria that were then cultured overnight at $37{ }^{\circ} \mathrm{C}$ with $50 \mu \mathrm{g} / \mathrm{ml}$ ampicillin. The cDNA was then extracted, purified (QIAquick PCR Purification Kit, Qiagen, Inc.) and sequenced. Full-length TSH $\beta$ sequences were obtained by aligning overlapping nucleotide sequences using Sequencher ${ }^{\mathrm{TM}} 4.5$ software (Gene Codes Corp., Ann Arbor, MI) and analyzed against sequences for TSH $\beta$ from other vertebrates by the ClustalW Method (Lasergene software; DNASTAR, Inc., Madison, WI).

Full-length cDNA sequences for fathead minnow TSH $\beta$ were confirmed by PCR using primers designed to the $5^{\prime \prime}$ and $3^{\prime \prime}$ untranslated region (UTR). These primers were (forward) $5^{\prime}$-ATCCTGAAACCCTGCC AGCTATA- $3^{\prime \leftarrow}$ and (reverse) 5'-CATTAAAGTTGGCAGAAGGTCT ATTATC $-3 \div$ Reverse-transcribed total RNA from pooled pituitary glands of both female and male minnows was amplified separately in $50 \mu \mathrm{l}$ PCRs containing $2.5 \mu \mathrm{l}$ of cDNA template, $38.5 \mu \mathrm{l}$ nuclease-free $\mathrm{H}_{2} \mathrm{O}, 5 \mu \mathrm{l} 10 \times$ buffer, $1 \mu \mathrm{l}$ dNTP mix, and $1 \mu \mathrm{l}$ Taq DNA polymerase (BD Advantage ${ }^{\mathrm{TM}} 2$ PCR Enzyme System, Clontech Laboratories, Inc., Mountain View, CA) under a profile of $95^{\circ} \mathrm{C}$ for 2 min followed by 30 cycles of $95^{\circ} \mathrm{C}$ for $30 \mathrm{~s}, 57^{\circ} \mathrm{C}$ for $30 \mathrm{~s}$, and $72^{\circ} \mathrm{C}$ for $1 \mathrm{~min}$, and then $72{ }^{\circ} \mathrm{C}$ for $2 \mathrm{~min}$. The PCR products were examined on a $1.2 \%$ agarose gel, and bands were excised, purified and sequenced

\subsection{PCR for TSH $\beta$ in genomic DNA}

Chromosomal DNA was isolated from the whole brain of adult female fathead minnows using a DNeasy Kit (Qiagen, Inc.) with an additional treatment of RNaseA. We then performed PCR on the genomic DNA to determine whether the multiple cDNA variants that we identified for TSH $\beta$ resulted from multiple genes.

A set of gene-specific primers was designed to amplify TSH $\beta$ from genomic DNA. The forward primer for this PCR was designed to the TSH $\beta$ open-reading frame upstream of intron 2 identified previously in TSH $\beta$ from fish (Sohn et al., 1999; Han et al., 2004) and other vertebrates (Kawasaki et al., 2003). The reverse primer was designed to the $3^{\prime \prime}$ UTR. The primers used for this PCR were (forward) 5'-ACCATCTGCATGGGCT 
TCTGCTTC-3' and (reverse) 5'-ACAATTGCACCCAGTCAACTGCTA CAA- $3^{\prime}$. Genomic DNA was amplified in a $50 \mu \mathrm{l}$ PCR containing $1.0 \mu \mathrm{l}$ of DNA template $(100 \mathrm{ng}), 37.6 \mu \mathrm{l}$ nuclease-free $\mathrm{H}_{2} \mathrm{O}, 5 \mu \mathrm{l} 10 \times$ buffer, $3 \mu \mathrm{l} \mathrm{MgCl}_{2}, 1 \mu \mathrm{l} \mathrm{dNTP}$ mix, $0.4 \mu \mathrm{l}$ Taq DNA polymerase (Promega), and $1 \mu \mathrm{l}$ of each primer using a thermal profile of $95^{\circ} \mathrm{C}$ for $2 \mathrm{~min}$ followed by 33 cycles of $95^{\circ} \mathrm{C}$ for $30 \mathrm{~s}, 59^{\circ} \mathrm{C}$ for $30 \mathrm{~s}$, and $72^{\circ} \mathrm{C}$ for $30 \mathrm{~s}$, and then $72{ }^{\circ} \mathrm{C}$ for $2 \mathrm{~min}$. The PCR products were examined on a $2 \%$ agarose gel.

\subsection{Sequencing of TSH $\beta$ from genomic DNA}

Genomic DNA was amplified in a $50 \mu \mathrm{l}$ PCR containing $1.5 \mu \mathrm{l}$ of DNA template (180 ng), $25 \mu \mathrm{l} \mathrm{GoTaq}{ }^{\circledR}$ Green Master Mix (Promega), $21.5 \mu \mathrm{l}$ nuclease-free $\mathrm{H}_{2} \mathrm{O}$, and $1 \mu \mathrm{l}$ each of forward and reverse primer $(10 \mu \mathrm{M})$ using a thermal profile of 1 cycle of $95^{\circ} \mathrm{C}$ for $2 \mathrm{~min}$ and 30 cycles of $95^{\circ} \mathrm{C}$ for $30 \mathrm{~s}, 51^{\circ} \mathrm{C}$ for $30 \mathrm{~s}$ and $72{ }^{\circ} \mathrm{C}$ for $3 \mathrm{~min}$, followed by a final extension of $72{ }^{\circ} \mathrm{C}$ for $5 \mathrm{~min}$. Primer pairs used were either forward primer $\left(5^{\prime}-\right.$ ATCCTGAAACCCTGCCAGCTATA-3') or forward primer (5'-GAA GATGTGATCCATACTACAACCAGAG-3'), each paired with the reverse primer (5'-AAACACTGCCGATCAAACATTAAAG- $\left.3^{\prime}\right)$. Both primer pairs produced clear, single bands of $2.5-$ or $1.6-\mathrm{kb}$ on a $2 \%$ agarose gel (Invitrogen, Inc.).

PCR products from these reactions were purified, ligated into plasmid. Ampicillin resistant bacteria were cultured overnight, and recombinant colonies were confirmed by PCR using the primers forward $\left(5^{\prime}-\mathrm{CCC}\right.$ ATTGGCCTCACTACACAA- $\left.3^{\prime}\right)$ and reverse (5'-ACCACTATTGGCC TCATAAAAGACATCAGATGCTTG- $3^{\prime}$ ). Plasmid DNA was then sequenced as described above. Primers used in the sequencing reactions including the vector primers T7 and U-19 and the following TSH $\beta$-specific primers: forward 5'-CCCATTGGCCTCACTACACAA-3', forward 5'CCCTAATACCTTTACCCTAACC- $3^{\prime}$, reverse $5^{\prime}$-CCAACTCCTTCAC ATTACTGTC- $3^{\prime}$, and reverse 5'-ACCACTATTGGCCTCATAAAAGA CATCAGATGCTTG-3'‘

\subsection{Southern blot analysis}

Genomic DNA was isolated from the fathead minnow brain as described. DNA $(10 \mu \mathrm{g})$ was digested with HincII overnight at $37^{\circ} \mathrm{C}$, and then electrophoresed on a $1 \%$ agarose gel and transferred to a nylon membrane. Hybridizations were carried out overnight at $42{ }^{\circ} \mathrm{C}$ with a probe labeled with digoxigenin-11-dUTP. This 280 -bp probe was specific to the open-reading frame of fathead minnow TSH $\beta$ and was generated by PCR using the primers (forward) 5'-GTGAAGGAATTGGTGGGTCCTCG TTTCC- $3^{\prime \leftarrow}$ and (reverse) $5^{\prime}$-CTCATACTG(G/T)TCCCAATA(C/T)GC (C/T)TGG-3 $3^{\prime}$ using a thermal profile of $95^{\circ} \mathrm{C}$ for 2 min followed by 25 cycles of $95^{\circ} \mathrm{C}$ for $30 \mathrm{~s}, 57^{\circ} \mathrm{C}$ for $30 \mathrm{~s}$, and $72^{\circ} \mathrm{C}$ for $1 \mathrm{~min}$, and then $72^{\circ} \mathrm{C}$ for $2 \mathrm{~min}$. Prior to hybridization, the DIG-labeled probe was denatured at $99^{\circ} \mathrm{C}$ for $10 \mathrm{~min}$. After hybridization, washes were performed as follows: $2 \times 15 \mathrm{~min}$ with $2 \times \mathrm{SSC} / 0.1 \% \mathrm{SDS}$ at room temperature, $2 \times 15$ min with $0.5 \times \mathrm{SSC} / 0.1 \% \mathrm{SDS}$ at $65^{\circ} \mathrm{C}$, and $30 \mathrm{~min}$ in $1 \times$ blocking buffer at room temperature. Primary anti-digoxygenin antibody $(1: 10,000$; Roche, Ltd., Basel, Switzerland) was applied for $30 \mathrm{~min}$ at room temperature, and the membrane was washed with $0.3 \%$ Tween 20 in $0.1 \mathrm{M}$ maleic acid with $0.15 \mathrm{M} \mathrm{NaCl}$. The hybridization signals and size markers were visualized with a $\mathrm{CSPD}^{\circledR}$ chemiluminescent alkaline phosphatase substrate and photographed (Kodak Image Station 440CF).

\section{Results and discussion}

\subsection{Isolation of multiple full-length $c D N A s$ for $T S H \beta$}

Here, we provide evidence that fathead minnow have multiple mRNA variants for TSH $\beta$-subunit in the pituitary, including one atypical variant that has a deduced protein sequence with an extension of 15 amino acids on the $\mathrm{C}$ terminus. Initially, we isolated and sequenced a 342-bp cDNA fragment of TSH $\beta$ from the pooled pituitary tissues of female minnows. This 342-bp amplicon was $94-88 \%$ identical to the TSH $\beta$ subunit from other Cyprinid fishes. Primers designed to this partial sequence were then used in RACE RT first-strand cDNA reactions to synthesize the full-length sequence. Three full-length cDNA sequences for TSH $\beta$ were identified with lengths of 1184-bp (GenBank Accession No. DQ677879), 1093-bp (GenBank Accession No. DQ677880) and 818-bp (GenBank Accession No. DQ677881).

Sequence analyses of the three cDNA variants for fathead minnow TSH $\beta$ revealed that the cDNA variant of 1184-bp included 453-bp of open-reading frame that encodes 150 amino acids including a 19 residue signal peptide and a mature TSH $\beta$ protein of 131 residues (Fig. 1a). This 1184bp cDNA also had 610-bp of $3^{\prime \prime}$ UTR which included a poly(A) signal sequence (AUUAAA). The 1093-bp cDNA variant of TSH $\beta$ was nearly identical to the 1184-bp variant from the $5^{\prime}$-end to the poly(A) signal, although we obtained 40-bp less of the $5^{\prime}$ UTR. This cDNA also contained a single deletion of 40-bp in the $3^{\prime \prime}$ UTR (Fig. 1a). The 818-bp cDNA variant, however, contained 498-bp nucleotides of openreading frame followed by 227-bp of $3^{\prime}$ UTR and a poly(A) signal (Fig. 1b). This variant had an unusual deletion of a 332-bp nucleotide segment which included part of the $3^{\prime \prime}$ UTR and the stop codon for the open-reading frame of the 1184- and 1093-bp cDNAs. The deletion of the expected stop codon generated an open-reading frame with a deduced amino acid sequence containing 15 additional residues on the carboxy terminus of the mature protein (Fig. 1b and c). Otherwise, however, the overall deduced amino acid sequence for the 818 -bp variant was $99.2 \%$ identical to the sequences for the 1184- and 1093-bp TSH $\beta$ variants.

We confirmed the presence of these three variants in the pituitary of males and females using RT-PCR. Gene-specific primers were designed to the common $5^{\prime}$ and $3^{\prime \prime}$ UTRs of the three cDNA variants and used to amplify full-length cDNA products from reverse-transcribed total RNA of

Fig. 1. The full-length nucleotide and deduced amino acid sequences of the (a) 1184- and 1093-bp (b) and 818-bp cDNA variants for TSH $\beta$ in fathead minnow. The predicted open-reading frame is shown in capital letters with the 19 amino acid signal peptide (underline), start and stop codons (black highlight boxes), and polyadenylation signal (double underline). The 40-bp segment (boxed, nucleotide basepairs +400 to +440 ) missing from the 1093 -bp cDNA variant is shown in (a). The 332-bp segment deleted from the 818-bp variant is highlighted in gray in (a), and the expected stop codon (based on the 1184- and 1093-bp cDNA variants) is outlined by a box (basepairs +394 to +396) in (b). (c) Graphical illustration of how a deletion of the 332-bp segment from the 1184-bp cDNA variant generates the 818-bp cDNA variant with a 15 amino acid extension of the open-reading frame. (d) PCR using genespecific primers to common $5^{\prime}$ and $3^{\prime}$ UTRs revealed that the $5^{\prime \prime}$ RACE-ready cDNA product (lane 1) and reverse-transcribed pooled pituitary total RNA from female (lane 2) and male (lane 3) minnows all produced two major PCR products. Sequencing of these bands revealed that the upper band comprised the 1184- and 1093-bp cDNA variants for TSH $\beta$, and the lower band represented the 818-bp variant for TSH $\beta$. 
pooled pituitary tissues from female and male minnows separately. Multiple distinct cDNA products were generated from both female and male pituitary total RNA
(Fig. 1d). Excision and sequencing of these bands confirmed that they consisted of the three cDNAs identified previously.

a -14

acgcgggggtgtctgtataagagcagaagccttcaacacaagcaggttaaagcagatcctcctagacatcctgaaacc

ctgccagctata

ATGTCTCCTCTGTATGTGGTTGGCATGCTGGGACTTTTGATGAAGATATCAGCACCT

ATGTGTGCCCCCACTGAGTCCACCATTTACTTCGAGAGACAGGAGTGTAACTACTGT

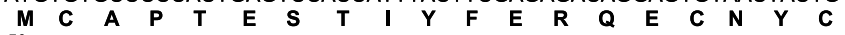

$+58$

GTGGCTGTCAACACCACCATCTGCATGGGCTTCTGCTTCTCCAGGGACAGTAATGTG

$\begin{array}{lllllllllllllllllll}\mathbf{V} & A & \mathbf{V} & \mathbf{N} & \mathbf{T} & \mathbf{T} & \text { I } & \mathbf{C} & \mathbf{M} & \mathbf{G} & \mathbf{F} & \mathbf{C} & \mathbf{F} & \mathbf{S} & \mathbf{R} & \mathbf{D} & \mathbf{S} & \mathbf{N} & \mathbf{V}\end{array}$

AAGGAGTTGGTGGGTCCTCGTTTCCTGGTTCAGAGAGGCTGCACCTATCAGGAAGTC

$\begin{array}{lllllllllllllllllll}\mathbf{K} & \mathbf{E} & \mathbf{L} & \mathbf{V} & \mathbf{G} & \mathbf{P} & \mathbf{R} & \mathbf{F} & \mathbf{L} & \mathbf{V} & \mathbf{Q} & \mathbf{R} & \mathbf{G} & \mathbf{C} & \mathbf{T} & \mathbf{Y} & \mathbf{Q} & \mathbf{E} & \mathbf{V}\end{array}$

$+172$

GAGTATCGGACGGCCATCTTGCCTGGCTGTCCTTCATATGCAGATCCTCACTTCACC

$\begin{array}{rllllllllllllllllll}\mathbf{E} & \mathbf{Y} & \mathbf{R} & \mathbf{T} & \mathbf{A} & \mathbf{I} & \mathbf{L} & \mathbf{P} & \mathbf{G} & \mathbf{C} & \mathbf{P} & \mathbf{S} & \mathbf{Y} & \mathbf{A} & \mathbf{D} & \mathbf{P} & \mathbf{H} & \mathbf{F} & \mathbf{T}\end{array}$

TATCCAGTGGCACTTAGTTGCCACTGCAGCACCTGTAACACCCACAGTGACGAATGT

$\begin{array}{rllllllllllllllllll}\mathbf{Y} & \mathbf{P} & \mathbf{V} & \mathbf{A} & \mathbf{L} & \mathbf{S} & \mathbf{C} & \mathbf{H} & \mathbf{C} & \mathbf{S} & \mathbf{T} & \mathbf{C} & \mathbf{N} & \mathbf{T} & \mathbf{H} & \mathbf{S} & \mathbf{D} & \mathbf{E} & \mathbf{C}\end{array}$

GCCCACAAAACCAGCAGCGCTGCAAGGAAATGCTCCAAACCTGTCCGACATCTGTAC

$\begin{array}{lllllllllllllllllll}A & H & K & T & S & S & A & A & R & K & C & S & K & P & V & R & H & L & Y\end{array}$ $+343$ CCCGACCCCGAGgAGAACAGTTACATCCAGCCATATTGgGAACAGTACGAGTAAtgt

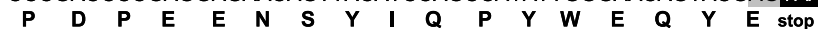

$+400 \quad+440 \quad+$ ttgatcattcatttcttgactaaaacttaaaaggatgctccacttttgggaaatgggetcatttacaatttttaccgttttgaatcaat ttgatcattcatttcttgactaaaacttaaaaggatgctc cacttttgggaaatgggctcattttacaattttaccgtttttgaatcaatt ggaagtcaatgagaccagaggctgtctggttacagatattcttctgaatatcaggaagtcggctgaatggattcgaaaacggta aaactctgtttaactctggggggagttgtaaaatgagcctatttccaaaaaagtggagtatccctttaatttaaaacaaagtgtgtgtg tgttgtagcagttgactgggtgcaattgtttgttagataatcattgagtaacctttcaagttacctaacttattatgtttgctgtatttatatc

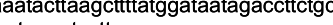
caactttaatgacgctttaacgtttgatcggcagtgtttctataaaaaattaaaagtaaaatccttcaaaaaaaaaaaaaaaaaa aaaaaaaaa

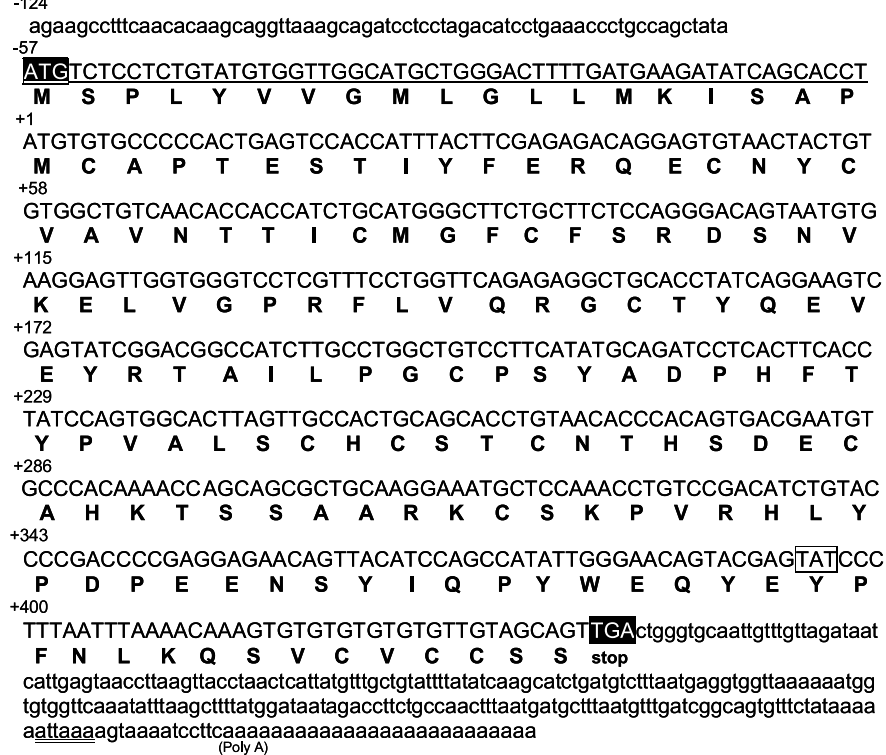

C

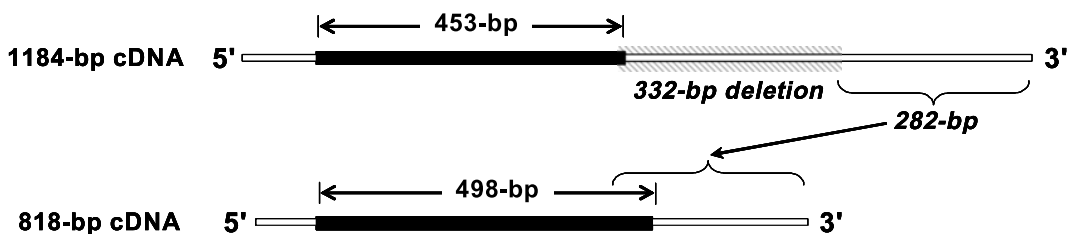

d

1600-bp

1000-bp-

500-bp-

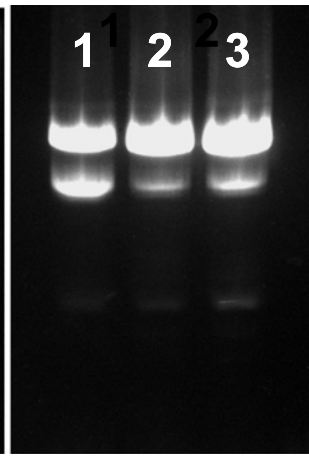




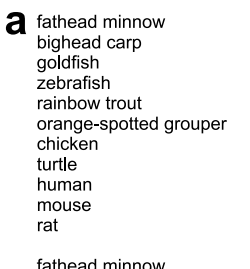

fathead minnow bighead carp

goldfish

zebrafish

rainbow trout

orange-spotted grouper

chicken

turtle

human

mouse

fathead minnow

bighead carp

goldfish

zebrafish

rainbow trout

orange-sp

chicken

human

mouse

rat

fathead minnow

bighead carp

goldfish

zebrafish

orange-spotted grouper

chicken

turtle

mouse
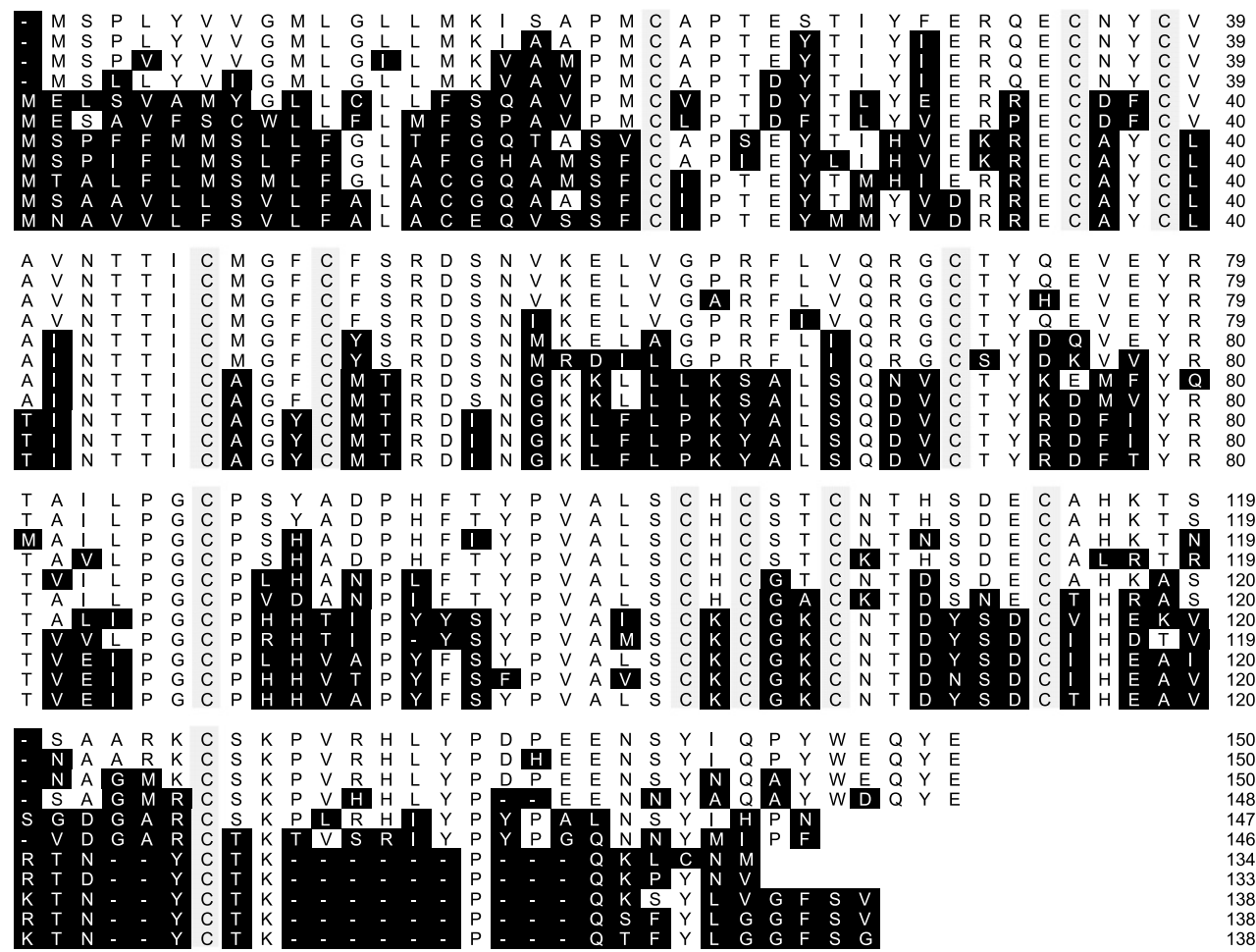
W fathead minnow TSH
fathead minnow TSH
(818-bp cDNA) human LH

human CG

horse LH / CG
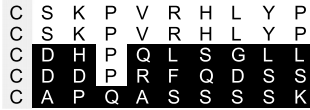

Fig. 2. (a) CLUSTAL W multiple sequence alignment of the deduced amino acid sequence of the open-reading frame for fathead minnow TSH $\beta$ (1184-bp cDNA variant) and TSH $\beta$ from other vertebrates. Black highlights designate amino acid changes in comparison to fathead minnow, and the 12 conserved cysteine residues are designated as grey highlighted letters. Amino acid sequences are provided in one-letter IUPAC code. Accession numbers and citations for nucleotide sequences using for the multiple alignment are as follow: bighead carp (AF177471); common carp (AB003585); goldfish (AB003584); zebrafish (AY135147); rainbow trout, Oncorhynchus mykiss (D14692; Ito et al., 1993); orange-spotted grouper, Epinephelus coioides (Wang et al., 2004); chicken (AF033495; Gregory and Porter, 1997); Chinese soft-shelled turtle, Pelodiscus sinensis (AY618874; Chien et al., 2006); human (M21024; Wondisford et al., 1988); mouse (M54943; Kourides et al., 1984), and rat (X01454). (b) Alignment of deduced amino acid sequences of the 1184-bp cDNA and 818-bp cDNA variants from fathead minnow with human luteinizing hormone $\beta$-subunit (hLH $\beta$ ) (X00264), human chorionic gonadotropin $\beta$-subunit (hCG $\beta$ ) (X00265; Talmadge et al., 1984), and horse chorionic gonadotropin $\beta$-subunit (horse LH $\beta /$ CG $\beta$ ) (S41704; Sherman et al., 1992).

Alignment of the protein sequence of fathead minnow TSH $\beta$ with teleosts and other taxa (Fig. 2) revealed high homology to TSH $\beta$ from other Cyprinid fishes and lower identity to TSH $\beta$ from other teleosts and birds, reptiles and mammals (Table 1). Interestingly, the deduced amino acid sequence of the 818-bp TSH $\beta$ cDNA variant from fathead minnow has an extended $\mathrm{C}$ terminus, which also occurs in human chorionic gonadotropin $\beta$-subunit $(\mathrm{hCG} \beta)$ and horse luteinizing hormone/chorionic gonadotropin $\beta$-subunits (horse LH $\beta / \mathrm{CG} \beta$ ) (Sherman et al., 1992; Talmadge et al., 1984).

\subsection{Sequencing of TSH $\beta$ gene and its comparison to $c D N A$ variants}

Full-length PCR using gene-specific primers designed to the $5^{\prime \prime}$ and $3^{\prime \prime}$ UTRs of fathead minnow TSH $\beta$ revealed only a single product of approximately $1.8-\mathrm{kb}$ in genomic DNA (Fig. 3a), suggesting a single gene for TSH $\beta$ in fathead min- now. This $1.8-\mathrm{kb}$ product includes intron 2 identified previously in the TSH $\beta$ gene of other vertebrates (Pradet-Blade et al., 1998; Sohn et al., 1999; Kawasaki et al., 2003; Han et al., 2004; Szkudlinski et al., 2002). We further explored this result using Southern blotting with the HincII restriction enzyme. HincII was selected specifically because of its restriction sites; if the 1184- and 818-bp cDNA variants were products of two distinct genes, then Southern blot analysis using HincII would produce two discrete bands differing by 332-bp in size (one band $\sim 1.8$-kb and a second band of $\sim 1.5-\mathrm{kb}$ ). Instead, Southern blotting produced only a single band of $\sim 1.8$-kb size (Fig. $3 b$ ).

Sequencing of the genomic PCR product revealed two exons containing 159- and 294-bp, respectively, of coding region for TSH $\beta$ (Fig. 4a; GenBank Accession No. EF590263). These exons were separated by a 1140-bp intron corresponding to intron 2 . In the $3^{\prime \prime}$ UTR of this gene, we identified a hairpin loop structure generated by two fully complementary $31-\mathrm{bp}$ regions of the $3^{\prime-} \mathrm{UTR}$. 
Table 1

Comparison of percentage identity of signal and mature TSH $\beta$ protein between fathead minnow (1184-bp cDNA variant) and other vertebrates

\begin{tabular}{lll}
\hline Species & Signal peptide $(\%)$ & Mature peptide $(\%)$ \\
\hline Bighead carp & 94.7 & 96.9 \\
Common carp & 73.7 & 93.1 \\
Goldfish & 73.7 & 89.3 \\
Zebrafish & 73.7 & 85.3 \\
Rainbow trout & 26.3 & 72.4 \\
Atlantic salmon & 26.3 & 71.4 \\
Orange-spotted grouper & 21.1 & 61.1 \\
European eel & 21.1 & 53.5 \\
Japanese eel & 26.3 & 52.8 \\
Chicken & 21.1 & 45.6 \\
Chinese soft-shell turtle & 15.8 & 46.0 \\
Human & 21.1 & 41.5 \\
Rat & 10.5 & 40.7 \\
Mouse & 10.5 & 39.8 \\
\hline
\end{tabular}

GenBank accession numbers not provided elsewhere are as follows: European eel, Anguilla anguilla (X73493); Japanese eel, Anguilla japonica (AY158008).

This hairpin loop was estimated from electrophoresis to be approximately $300-\mathrm{bp}$ in length. The hairpin loop structure was located 25-bp from the end of the TSH $\beta$ stop codon and corresponded to the region of deletions in the 1093and 818 -bp cDNA variants (Fig. 4b).

While this study provides the first evidence of transcript variants for TSH $\beta$ in fathead minnow, multiple cDNAs for TSH $\beta$ have been documented in other taxa. In goldfish, Yoshiura et al. (1999) identified two mRNAs for TSH $\beta$ that differed by 300-bp in length in the $3^{\prime \prime}$ UTR. These variants result from two polyadenylation sites in the $3^{\prime \prime}$ UTR, since Southern blot analysis of goldfish DNA indicated only a single TSH $\beta$ gene. Xenopus laevis has been similarly shown to produce variants for TSH $\beta$ transcripts due to multiple polyadenylation sites (Buckbinder and Brown, 1993). Some individuals of European eel (Anguilla anguilla) have also been shown to produce two transcripts for TSH $\beta$ (Pradet-Blade et al., 1997). These transcripts are generated by a $26-42-b p$ minisatellite in the $3^{\prime \prime}$ UTR of the TSH $\beta$ gene (Pradet-Blade et al., 1998).

What process contributes to the production of three mRNA variants for TSH $\beta$ in fathead minnow is not fully clear. The 40- and 332-bp 3'UTR deletions that characterize the 1093- and 818-bp variants, respectively, are not located at a known intron-exon boundary typical of mRNA variants generated by alternative splicing. Long hairpin loops $(>100-b p)$ such as the one identified in the fathead minnow TSH $\beta$ gene can act as binding sites for proteins, protect mRNA from degradation, and induce RNA silencing (Svoboda and Di Cara, 2006). Long hairpin loops, however, may also be a site for post-transcriptional mRNA editing. Adenosine deaminases that act on RNA (ADARs) are RNA-editing enzymes that convert adenosine to inosine (recognized as guanosine) in doublestranded RNAs, effectively altering RNA structure. ADARs have been shown to act on hairpin loops in the non-coding $3^{\prime \leftarrow}$ UTR of mRNAs from both vertebrates
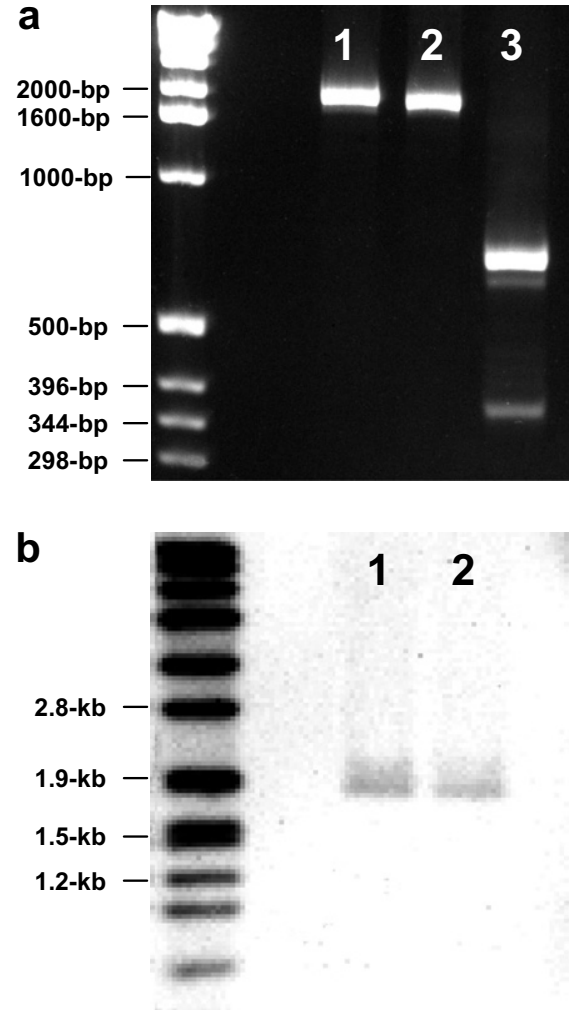

Fig. 3. (a) Products of PCR using gene-specific TSH $\beta$ primers and genomic DNA of two female minnows (columns 1 and 2) and total RNA from the pooled pituitary tissues of 12 female minnows (column 3 ). Genomic DNA produced only a single PCR product of $1.8-\mathrm{kb}$ containing the 2 nd intron of the TSH $\beta$ gene and the open-reading frame. Reverse-transcribed total RNA, however, revealed three distinct PCR products corresponding to the predicted sizes for the three TSH $\beta$ cDNA variants. (b) Southern blot analysis of the TSH $\beta$ gene in fathead minnow. Genomic DNA from the brains of two female minnows was digested using the HincII restriction enzyme. Digestion with HincII was predicted to generate two discrete bands differing by 332-bp if the 1184- and 818-bp cDNA variants were produced by separate genes. Southern blotting, however, produced only one band of $1.8-\mathrm{kb}$ suggesting a single gene for TSH $\beta$ in fathead minnow.

and invertebrates (Morse et al., 2002), and it is possible that post-transcriptional processing by ADARs or a similar mechanism contributes to the generation of multiple $\mathrm{TSH} \beta$ transcripts in the fathead minnow.

Alternatively, there may be another TSH $\beta$ gene in fathead minnow that we have not identified. Genomic PCR and Southern blot analyses imply only one TSH $\beta$ gene, but two pieces of evidence suggest that multiple genes may be present. First, the 1184- and 1093-bp cDNA sequences do not contain the 300-bp hairpin loop structure seen in the TSH $\beta$ gene shown in Fig. 4. The 818-bp transcript, in contrast, shows a 332-bp deletion in the $3^{\prime}$ UTR corresponding to the location of the hairpin loop structure. Second, the 818 -bp variant shows greater sequence similarity in the $3^{\prime \prime}$ UTR to the gene than does either of the other variants. This similarity includes several small (1-7 bp in length) changes in the $3^{\prime \prime}$ UTR that were shared between the gene and 818bp variant, but not present in the 1184- and 1093-bp cDNAs (Fig. 4c). It should be noted, however, that pituitary tissues 
a

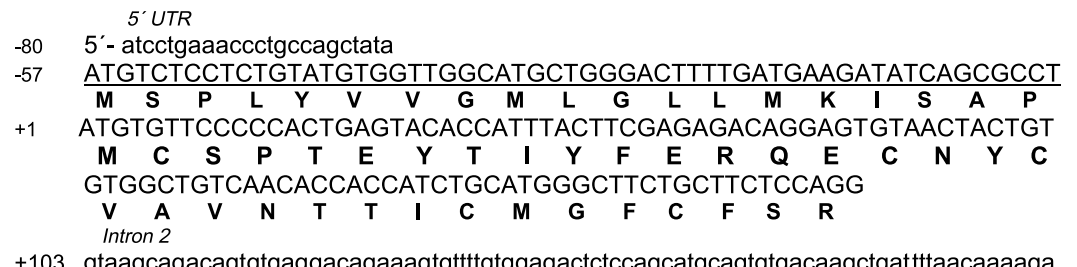

+103 gtaagcagacagtgtgaggacagaaagtgtttgtggagactctccagcatgcagtgtgacaagctgattttaacaaaaga cgatatatctgtcaccgtttacccacacccatgccaaacatgtgaatttcgctcttccgtggaacacaaacgagattttccattc catttcattttgtgttccagggaataacaaagatcatactctctttaaagtaaatgtccatttcacccacaaatgaaaattctgtcat taattacctgcgtttctgtgtagatgtcactattgttcagtactagcaggctag ccttttgcctgtgtttaggttgatgttagtttata gaagacagaggggggaaactaccattagagacagtagtgcgtcagaaaacaaggtgaaaggaagaagttgaacatca aggaggataaaagcagtgagggtgataacagagatgaagaatataaattatagattgttgtggaagtccggcatttgagta cattatcctatcctatgttggaagatgtgatccatactacaaccagaggtcaggaaagacaccactgcccattggcctcacta cacaagcaggggtgctccataaatgatgactaaacatgtcaaatccagttatacactgaaaacgtcttgtcgattttcacttgtg ctacaattggtttggaattccaagaaagaaacaatgttaaaatc aatgtgatgtttttgaaacactaagacctttccactactttt cagactgtgaaaatgcatttaagtgtatgtgaagtttcagaaaatttgccaaaattatttaccctaatacctttaccctaaccttac catttataaatgacagcactgtaaaaaaaaaaaaaaaaaaaaaaaaaacagattttgggaaatgattttatacttaaat $\mathrm{g}$ tatgtaaaatataaagtaattttttttctatagctgtgatttcataattagtcccaaaaatgttaaaagggtttaacttttctttgcactg aaaagggccataattgatttaataaacaatttatttaagaaacaaaaccctcaaatgtttctgaaatgattaagtggcaatttg gctaaatatgcatctctacattcatcctatag

+1243 GACAGTAATGTGAAGGAGTTGGTGGGTCCTCGTTTCCTGGTTCAGAGGGGCTGC

$\begin{array}{llllllllllllllllll}D & S & N & V & K & E & L & V & G & P & R & F & L & V & Q & R & G & C\end{array}$

ACCTATCAGGAAGTCGAGTATCGGACGGCCATCTTGCCTGGCTGTCCTCCATAT

$\begin{array}{llllllllllllllllll}\mathbf{T} & \mathbf{Y} & \mathbf{Q} & \mathbf{E} & \mathbf{V} & \mathbf{E} & \mathbf{Y} & \mathbf{R} & \mathbf{T} & \mathbf{A} & \mathbf{I} & \mathbf{L} & \mathbf{P} & \mathbf{G} & \mathbf{C} & \mathbf{P} & \mathbf{P} & \mathbf{Y}\end{array}$

GCAGATCCTCATTTCACCTATCCAGTGGCACTTAGTTGCCACTGCAGCACCTGTAAC

$\begin{array}{llllllllllllllllllll}A & D & P & H & F & T & Y & P & V & A & L & S & C & H & C & S & T & C & N\end{array}$

ACCCACAGTGACGAATGTGCCCACAAAACCAGCAGCGCTGCAAGGAAGTGCTCC

$\begin{array}{llllllllllllllllll}T & H & S & D & E & C & A & H & K & T & S & S & A & A & R & K & C & S\end{array}$

AAACCTGTCCGACATCTGTACCCCGACCCCGAGGAGAACAGTTACATCCAGTCATAT

$\begin{array}{llllllllllllllllllll}K & P & V & R & H & L & Y & P & D & P & E & E & N & S & Y & I & Q & S & Y\end{array}$

TGGGAACAGTACGAGTAA

$\begin{array}{lllllll}\mathbf{W} & \mathbf{E} & \mathbf{Q} & \mathbf{Y} & \mathbf{E} & \text { stop }\end{array}$

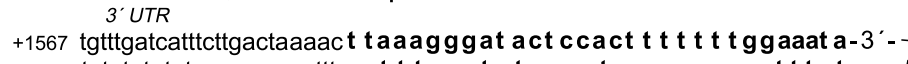

tgtgtgtgtgtgaaacaaaattt aat $\mathrm{t} t$ ccct at gagg $\mathrm{t}$ gaaaaaaacct $\mathrm{t} t$ atccg -5

-5' -gtgttgtaagttgactgggtgcaattgttgttagataatcattgagtaac cttaagttacctaactca ttatgtttgctgtatttatatcaagcatctgatgtcttaatgaggtggttaaaaaatggtgtggttcaaata tttaagctttatggataatagaccttctgccaactttaatgatgctttaatgtttgatcggcagtgttt-3'

b
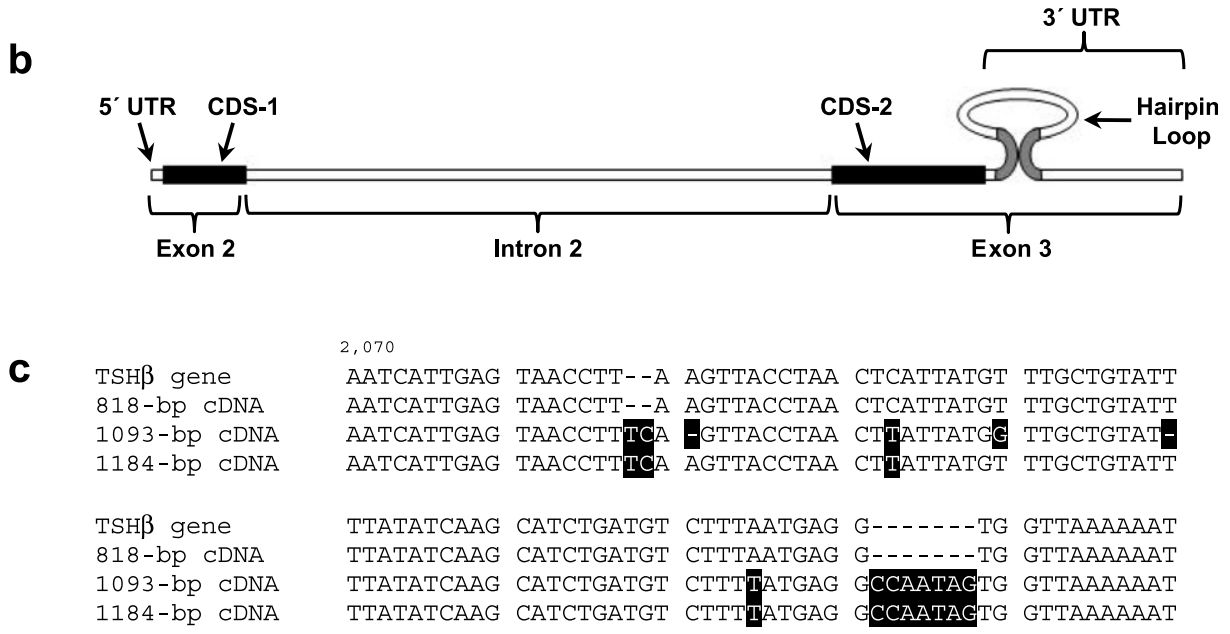

Fig. 4. (a) Nucleotide sequences of the $5^{\prime \prime} U T R$, intron 2 region and $3^{\prime \prime} U T R$ fragments of the TSH $\beta$ gene from fathead minnow. Coding region is shown in capital letters; non-coding regions are shown in lowercase. The region coding for the signal peptide of TSH $\beta$ is underlined. Exon 2 , containing part of the $5^{\prime}$ UTR and coding region (basepairs -80 to +102 ), and exon 3, containing the remainder of the coding region (basepairs +1243 to +1536 ) and part of the $3^{\prime \prime}$ UTR, were separated by intron 2 of 1140-bp (basepairs +103 to +1242 ). Beginning 25-bp after the stop codon (black highlighted box), two fully complementary, 31-bp regions of the 3'-UTR generated a hairpin loop estimated from gel pictures to be of $\sim 300$-bp. (b) Schematic representation of the TSH $\beta$ gene structure showing the position of the hairpin loop structure relative to the two coding regions (CDS-1 and CDS-2), UTRs and intron 2. (c) Alignment of partial 3'UTR nucleotide sequences of the TSH $\beta$ gene and 818-, 1093-, and 1184-bp cDNA variants. The gene and 818-bp transcript share several nucleotide changes in the $3^{\prime \prime}$ UTR including a 2-bp and a 7-bp deletion not present in the 1093- and 1184-bp transcripts. Basepair number represents alignment to the TSH $\beta$ gene (GenBank Accession No. EF590263).

were pooled to obtain sufficient RNA for the isolation and cloning of TSH $\beta$, so it is not clear whether three transcripts are present in all individuals.
The functional significance of these transcript variants also remains to be determined. Extensions and changes in sequence composition of $3^{\prime \prime}$ UTRs can alter transcript sta- 
bility as well as affect mRNA translation and cellular localization (Decker and Parker, 1995). Among the family of glycoprotein hormone $\beta$ subunits, only chorionic gonadotropins (CGs) and equine LH/CG $\beta$ have C-terminal peptide extensions with multiple serine-linked oligosaccharides, which evolved independently through a $3^{\prime}$-end extension of the LH $\beta$ gene open-reading frame (Jameson and Hollenberg, 1993; Li and Ford, 1998). The C-terminal extension with additional carbohydrate moieties does not alter overall conformation of the subunit but increases hCG's biological half-life (Matzuk et al., 1990) and alters its intracellular processing (Muyan and Boime, 1998). The C-terminal extension in the deduced amino acid sequence of the 818-bp variant of fathead minnow TSH $\beta$, however, bears little similarity to that of CG $\beta$ s (Fig. 2b) and contains three additional Cys residues, which could alter the disulfide bond arrangement and conformation of the protein. While a complete understanding of the functional significance of the TSH $\beta$ transcripts is beyond the scope of this current study, our findings illustrate how future investigations aimed at isolating transcripts for $\operatorname{TSH} \beta$ and other glycoproteins should take care to identify and sequence all transcripts present.

\section{Acknowledgments}

This research was supported by the West Coast Center for Oceans and Human Health as part of the NOAA Oceans and Human Health Initiative. The WCCOHH is part of the National Marine Fisheries Service's Northwest Fisheries Science Center, Seattle, WA. We thank Linda Park, Linda Rhodes, Steven Roberts, Adam Luckenbach and Larissa Felli for technical assistance, and Walt Dickhoff, Adam Luckenbach and two anonymous referees for comments that greatly improved the quality of this manuscript.

\section{References}

Ankley, G.T., Johnson, R.D., 2004. Small fish models for identifying and assessing the effects of endocrine-disrupting chemicals. ILAR J. 45, 469-483.

Ankley, G.T., Villeneuve, D.L., 2006. The fathead minnow in aquatic toxicology: past, present and future. Aquat. Toxicol. 78, 91-102.

Brown, S.B., Adams, B.A., Cyr, D.G., Eales, J.G., 2004. Contaminant effects on the teleost fish thyroid. Environ. Toxicol. Chem. 23, 16801701.

Buckbinder, L., Brown, D.D., 1993. Expression of the Xenopus laevis prolactin and thyrotropin genes during metamorphosis. Proc. Natl. Acad. Sci. USA 90, 3820-3824.

Chatterjee, A., Hsieh, Y.-L., Yu, J.Y.L., 2001. Molecular cloning of cDNA encoding thyroid stimulating hormone $\beta$ subunit of bighead carp Aristichthys nobilis and regulation of its gene expression. Mol. Cell. Endocrinol. 174, 1-9.

Chien, J.-T., Chowdhury, I., Lin, Y.-S., Liao, C.-F., Shen, S.-T., Yu, J.Y.L., 2006. Molecular cloning and sequence analysis of a cDNA encoding pituitary thyroid stimulating hormone $\beta$-subunit of the Chinese soft-shell turtle Pelodiscus sinensis and regulation of its gene expression. Gen. Comp. Endocrinol. 146, 74-82.
Decker, C.J., Parker, R., 1995. Diversity of cytoplasmic functions for the $3^{\prime \prime}$ untranslated region of eukaryotic transcripts. Curr. Opin. Cell Biol. 7, 386-392.

Gregory, C.C., Porter, T.E., 1997. Cloning and sequence analysis of a cDNA for the $\beta$ subunit of chicken thyroid-stimulating hormone. Gen. Comp. Endocrinol. 107, 182-190.

Han, Y.-S., Liao, I.-C., Tzeng, W.-N., Yu, J.Y.-L., 2004. Cloning of the cDNA for thyroid stimulating hormone $\beta$ subunit and changes in activity of the pituitary-thyroid axis during silvering of the Japanese eel, Anguilla japonica. J. Mol. Endocrinol. 32, 179-194.

Herzog, W., Zeng, X., Lele, Z., Sonntag, C., Ting, J.-W., Chang, C.-Y., Hammerschmidt, M., 2003. Adenohypophysis formation in the zebrafish and its dependence on Sonic hedgehog. Dev. Biol. 254, 3649.

Ito, M., Koide, Y., Takamatsu, N., Kawauchi, H., Shiba, T., 1993. cDNA cloning of the $\beta$ subunit of teleost thyrotropin. Proc. Natl. Acad. Sci. USA 90, 6052-6055.

Jameson, J.L., Hollenberg, A.N., 1993. Regulation of chorionic gonadotropin gene expression. Endocr. Rev. 14, 203-221.

Kawasaki, D., Aotsuka, T., Higashinakagawa, T., Ishii, S., 2003. Cloning of the gene for the thyrotropin $\beta$ subunit if the Japanese crested ibis, Nipponia nippon. Zool. Sci. 20, 203-210.

Kourides, I.A., Gurr, J.A., Wolf, O., 1984. The regulation and organization of thyroid stimulating hormone genes. Recent Prog. Horm. Res. 40, 79-120

Li, M.D., Ford, J.J., 1998. A comprehensive evolutionary analysis based on nucleotide and amino acid sequences of the $\alpha$ - and $\beta$-subunits of glycoprotein hormone gene family. J. Endocrinol. 156, 529-542.

Martin, S.A.M., Wallner, W., Youngson, A.F., Smith, T., 1999. Differential expression of Atlantic salmon thyrotropin $\beta$ subunit mRNA and its cDNA sequence. J. Fish Biol. 54, 757-766.

Matzuk, M.M., Hsueth, A.J.W., LaPolt, P., Tsafriri, A., Keen, J.L., Boime, I., 1990. The biological role of the carboxy-terminal extension of human chorionic-gonadotropin beta-subunit. Endocrinology 126, 376-383.

Morse, D.P., Aruscavage, P.J., Bass, B.L., 2002. RNA hairpins in noncoding regions of human brain and Caenorhabditis elegans mRNA are edited by adenosine deaminases that act on RNA. Proc. Natl. Acad. Sci. USA 99, 7906-7911.

Muyan, M., Boime, I., 1998. The carboxy-terminal region is a determinant for the intracellular behavior of the chorionic gonadotropin $b$ subunit: effects of the processing of the Asn-linked oligosaccharides. Mol. Endocrinol. 12, 766-772.

Pradet-Blade, B., Schmitz, M., Salmon, C., Dufour, S., Quérat, B., 1997. Down-regulation of TSH subunit mRNA levels by thyroid hormones in the European eel. Gen. Comp. Endocrinol. 108, 191-198.

Pradet-Blade, B., Salmon, C., Hardy, A., Quérat, B., 1998. Heterogenity of eel thyrotropin $\beta$ mRNAs is due to a minisatellite in the $3^{\prime \prime}$ untranslated region of the gene. Gene 215, 251-257.

Salmon, C., Marchelidon, J., Fontaine, Y.A., Huet, J.C., Querat, B., 1993. Cloning and sequence of thyrotropin $(\beta)$-subunit of a teleost fish, the eel (Anguilla anguilla L.). C. R. L'Acad. Sci. 316, 749-753.

Sherman, G.B., Wolfe, M.W., Farmerie, T.A., Clay, C.M., Threadgill, D.S., Sharp, D.C., Nilson, J.H., 1992. A single gene encodes the $\beta$ subunits of equine luteinizing hormone and chorionic gonadotropin. Mol. Endocrinol. 6, 951-959.

Sohn, Y.C., Yoshiura, Y., Suetake, H., Kobayashi, M., Aida, K., 1999. Isolation and characterization of the goldfish thyrotropin $\beta$ subunit gene including the $5^{\prime}$-flanking region. Gen. Comp. Endocrinol. 115, 463-473.

Svoboda, P., Di Cara, A., 2006. Hairpin RNA: a secondary structure of primary importance. Cell. Mol. Life Sci. 63, 901-918.

Szkudlinski, M.W., Fremont, V., Ronin, C., Weintraub, B.D., 2002. Thyroid-stimulating hormone and thyroid-stimulating hormone receptor structure-function relationships. Physiol. Rev. 82, 473-502.

Talmadge, K., Vamvakopoulos, N.C., Fiddes, J.C., 1984. Evolution of the genes for the $\beta$ subunits of human chorionic gonadotropin and luteinizing hormone. Nature 307, 37-40. 
USEPA, 2002. A short-term method for assessing the reproductive and developmental toxicity of endocrine-disrupting chemicals using the fathead minnow (Pimephales promelas). EPA-600/R-01/067. USEPA, Cincinnati, $\mathrm{OH}$.

Wang, Y., Zhou, L., Yao, B., Li, C.-J., Gui, J.-F., 2004. Differential expression of thyroid-stimulating hormone $\beta$ subunit in gonads during sex reversal of orange-spotted and red-spotted groupers. Mol. Cell. Endocrinol. 220, 77-88.
Wondisford, F.E., Radovick, S., Moates, J.M., Usala, S.J., Weintraub, B.D., 1988. Isolation and characterization of the human thyrotropin beta subunit gene: differences in gene structure and promoter function from murine species. J. Biol. Chem. 263, 12538-12542.

Yoshiura, Y., Sohn, Y.C., Munakata, A., Kobayashi, M., Aida, K., 1999. Molecular cloning of the cDNA encoding the $\beta$ subunit of thyrotropin and regulation of its gene expression by thyroid hormones in the goldfish, Carassius auratus. Fish Physiol. Biochem. 21, 201-210. 